\title{
Green Human Resource Management: a Access Device to Evade Exhaustion of Natural Resources
}

\author{
P. Praveen Kumar, K. C. Raja Shree
}

\begin{abstract}
The effect of our routine activities on environment results in natural resources deple-tion and elevated global warming. This is the foundation for evolution of such concept called green Human Resource Management (HRM). The universal attention for maintenance of eco-logical balance formulates green policies to be implemented in organizations. Therefore, companies commenced a green touch in HRM for accomplishing environmental sustainability. The processes of green HRM entwine the following steps. The foremost is centralization of document storage and usage followed by tweaking of temperature to avert disturbing of climate and atmosphere. Usage of energy efficient device like green refrigerator, in which coil should be replaced twice in a year to reduce emanation of greenhouse gases. The knowing capital should be safeguarded and benefits should be rendered to environment. This paper demonstrates about need and procedures concerned in green HRM. This also suggests the ways to employ green HRM in a business where ordinary HRM is in existence.
\end{abstract}

\section{INTRODUCTION}

Human Resources (HR) are contemplated as the ultimate conspicuous element in an organization. The workforce is enforced for an organization in order to scrutinize skills of employees. The organizations' budget is clearly maintained by human resources. The em-ployee's performances are and re-tained using various strategies. The environmental factors are interpreted and precautionary measures are determined with assistance of human resources. The Human Resource Man-agement (HRM) encompasses four prime ingredients. The beginning of process is human re-source planning. This step contains sequence of activities such as recruiting people, selecting correct people, hiring, training needs, induction and orientation to fresh employees, evaluation of performance, promoting deserving employees and layoff if necessary. The second step embraces remuneration for performance and giving added advantages to employees. The third step is estimation of employee's performance. The terminal step in human resource pro-cess is maintenance of enduring relationships with employees. Green HRM is utilization of policies to enhance sustainable usage of resources in an organization. The green HRM involves two essential components. The former is environmental friendly practices and latter is knowledge capital conservation. An exceptional HRM practice grabs a

Revised Manuscript Received on September 10, 2019.

Dr. P. Praveen Kumar, Asst. Professor, Saveetha School of Management, Saveetha nstitute of Medical and Technical Science, Chennai

, Tamilnadu, India

(email: praveenkselva@gmail.com)

Ms. K. C. Raja Shree, Asst. Professor, Saveetha School of Management, Saveetha Insti-tute of Medical and Technical Science, Chennai, Tamilnadu, India

(email: kcrajashree7@gmail.com) measured and if employees are required, they are attracted

tenacious role in adoption of techniques for environmental protection. This also magnifies the employer-employee relationship along with increased employee retention. This paper expands about green HRM and its procedures such as recruitment, selection, orientation, training, compen-sation, benefits and career development.

\section{REVIEW OF LITERATURE}

Mishra (2017) explored a model to overcome challenges faced by green HRM. The study suggests that construction of sustainable organization helps to attain green HRM. The decrees of study illustrates that top management support is highly essential for achieving green employee behavior.

Chaudhary (2018) examined the perception of employees towards green HRM. A strong affiliation is established between organization prestige and environmental orientation. The study highlights need for efficient integration of multifarious disciplines such as manag-ing environment and human resource.

Yong and Yusoff (2018) scrutinized the impact of strategically competencies of pro-fessionals in HR department on ratifying green HRM. The dominant ingredients of green HRM are strategic positioning and change implementation. The former is associated with green recruitment, selection, training, etc. The latter is associated with rewards and job posi-tions.

Yusliza et al. (2017) analyzed the impact of electronic HRM and employee empow-erment on practices of green HRM. A conceptual framework was developed in this study. The outcomes of this study show an affirmative relationship among above mentioned com-ponents. Business partnering can also be implemented for a better green practice.

Moraes et al. (2018) provides details regarding knowledge management in environ-mental aspects which is aflavor some constituent of green HRM. The survey comprised of 178 employees placed in largest banks at Brazil. The preponderant factors which are influ-encing green HRM are teamwork, empowerment, efficiency, etc.

Ragas et al. (2017) suggests the healthy green lifestyle would enhance performance of employees. Therefore, the green lifestyle of employees directly influences job performance in a constructive direction. The study is done in Eggnog of Philippines. This type of approach also contributes to organization and environment.

Fernandez et al. (2017) demonstrates that recruitment, selection, employee participa-tion, training, rewards, appraisal, etc can be strengthened with a substantial green 
HRM prac-tice. The study developed a mechanism called clean development for improving green prac-tices in human resource. The study is confined to Brazil.

Moreno et al. (2012) advocated that HRM in environment builds competitive ad-vantages in terms of cost and differentiation. The data is collected from 94 firms. The meth-odology employs least square analysis. This study also depicts about implementing pollution control strategies.

Richbell and Watts (2002) developed a concept called green field site. According to this concept, there are sites called green field which improves ways of green HRM practices. This may bring about innovations to the already existing culture. The concept considers con-centrations on geographical regions and improves employee-management relationship.

Baker (1999) explained that current trends in human resource have to be analyzed prior to implementation of green HRM. The strategic HRM should be integrated and com-bined with green HRM for obtaining optimum and desirable results. The specific issues arousing due to employment and employee relations have to be addressed as per this study.

Brierley and Gwilliam (2003) discussed about issues of human resources that have dominant impacts on audit firms. This can be ensured and made better with multi-disciplinary activities and appropriate research. The career development is an indispensable factor when the management of human resources is concerned.

Garavan et al. (2001) introduced a specific issue in human resource namely invention of new concepts and capital accusation of human resource. The human capital embraces per-formance, employability, etc while organizational capital includes skills, investment, knowledge, ownership, etc. Both the capitals should be safe guarded.

Green et al. (2000) showcased that human resources are pivotal and key component in sectors such as tourism and hospitality. Therefore, enhanced care should be exerted while implementing new concepts like green HRM. This study extended towards strategic signifi-cance of human resource and preservation of their interests in future.

Mayrhofer (1995) focuses on regulatory environment for a better HRM and green HRM practices. This study also analyses features of current trends practiced in maintenance of human resources. Kouhy et al. (2009) explained the major seven policies which are affect-ing human resource practices. Job for life, training, performance appraisal, recruitment, teamwork, pensions and organizational culture are the important factors that influences these practices. Moreover, a good scheme of pension would make the system advantageous.

\section{GREEN RECRUITMENT AND SELECTION}

The green recruitment means paperless process of recruitment with reduced impact on environment. The advertisements and applications are made available through online. This is a form of professional recruitment. Even for dwindling travel expenses, interviews are con-ducted through online. This approach facilitates in satisfying requirements of areas such as climatic change, renewable energy and sustainable development. Green recruitment assists in attaining sustainable development through better human resource practices (Saini and Shukla, 2016). These services extend search ranging from executives to contract. The selection pro-cess incorporates picking of right candidate for job vacancy through online media. This creates an eco-friendly environment in order to provide a healthy habitat for the upcoming gen-erations in planet. Talent management followed in organization is similar to winning a cham-pionship because of its tedious process (Hughes and Reg, 2008). A framework called green field site aids in consummation of perfect recruitment and selection in an organization (Halli-er, 2001).

\section{GREEN ORIENTATION AND TRAINING}

Employee orientation plays an exotic role in strengthening foundation of relationship laid by new employee in the organization. This makes the employee to feel a sense of comfort ability and confidence to adapt in an estranged atmosphere. When green HRM is imple-mented in employee orientation, the enhancement in retention rate is achieved. Green orienta-tion facilitates better office ambience. Meanwhile, efficacious training programs should be provided for employees to upgrade their performances in jobs performed. The green training would boost value of company in minds of employees. The training in green HRM helps in green job transitions and overcomes short run challenges in economy making it green econ-omy (Bowen et al. 2018). Green economy can be obtained and flourished only through the employment of green HRM in companies (Lebedev et al. 2015).The organizations show in-flated interests in green HRM because of return benefits obtained out of these processes (Ti-wari, 2017). The employee education is a direct measure to employee satisfaction. Green training stresses the responsibility and role of employees in their organization thereby making them to feel a sense of empowerment.

\section{GREEN COMPENSATION AND BENEFITS \& RESULTS}

Compensation should be provided to employees in both monetary as well as non-monetary aspects for retaining the employees within organization. The benefits given to employees will amplify their performance in job. The management of both human resource and environment should be assimilated to accomplish outstanding compensation practices (Siyambalapitiya et al. 2018). The benefits may be in form of bonus, lunch coupons, prizes, gifts, party, parking slots, etc. When green HRM is exerted it directly relates to corporate social responsibility. Sustainable strategies should be amalgamated with green HRM for ac-tualizing excellent social responsibility practices (Gholami et al. 2016). Corporate social responsibility increases the brand image of company. The green HRM specifically implemented in service sectors enhance the performances of hotel employees and thereby improve eco-friendly behavior (Kim et al. 2019). The medical expenses, travel benefits, retirement plans, insurance options also can be rendered to employees based on their performance and experi-ence. In some companies, 
stock provisions are being made available for employees of high cadre.

\section{GREEN CAREER DEVELOPMENT}

Career development refers to increase of individual career in a specific company. This is a major factor which makes the employees to continue in organization for an indefinite pe-riod of time. This is termed as employee growth in organization. This is purely based on skills, knowledge, experience and attitude of employees. The organizations should actively participate in cultivating excellent career choices for employees (Valickas et al. 2015). The internal promotions will reduce costs incurred in recruitment and selection procedures. The psychological capital must be considered for better career options. This would ensure finest career to employees ( $\mathrm{Gu}$ et al. 2019). Also the employees who are already familiar to organi-zation will handle company in a positive way leading to speedy growth and development. A luminous framework is required to construct career management traditions and career progression (Bagdadli and Gianecchini, 2018). Providing career development to employees be-comes an obligation for companies.

\section{CONCLUSION}

Green HRM has turned into a trending theme in corporate sector. The cultivation of green HRM among companies would probably assist in augmenting competitive advantage of company. The capacity of practical thinking by employees should be encouraged by man-agement. An effectual green HRM practices would facilitate healthy environment in compa-nies and thereby results in outstanding ambience for employees to work. Although, massive number of benefits are there, the huge conversion expense of green HRM makes the man-agement think twice before implementing it. Another important threat is green washing. This may create wrong perception among customers about companies' production processes and raw materials utilized. The laws indulged on green HRM may be tedious for companies to be followed. Inspite of advantages offered by green HRM, the cost aspects and implementation difficulties make it a question for implementation.

\section{REFERENCES}

1. Bagdadli, S., \&Gianecchini, M. (2018). Organizational career management practices and objective career success: A systematic review and framework. Human Resource Management Review.

2. Baker, D. (1999). Strategic human resource management: performance, alignment, management. Librarian Career Development, 7(5), 51-63.

3. Bowen, A., Kuralbayeva, K., \&Tipoe, E. L. (2018). Characterizing green employment: the impacts of 'greening'on workforce composition. Energy Economics, 72, 263-275.

4. Brewster, C., Mayrhofer, W., \& Morley, M. (Eds.). (2004). Human resource management in Europe: Evidence of convergence?.Routledge.

5. Brierley, J. A., \&Gwilliam, D. R. (2003). Human resource management issues in audit firms: a research agenda. Managerial Auditing Journal, 18(5), 431-438.

6. Carmona-Moreno, E., Céspedes-Lorente, J., \&Martinezdel-Rio, J. (2012). Environmental human resource management and competitive advantage. Management Research: Journal of the Iberoamerican Academy of Management, 10(2), 125-142.

7. Chaudhary, R. (2018, December). Can green human resource management attract young talent? An empirical analysis. In Evidence-based HRM: a Global Forum for Empirical Scholarship (Vol. 6, No. 3, pp. 305-319). Emerald Publishing Limited.

8. Christensen Hughes, J., \&Rog, E. (2008). Talent management: A strategy for improving employee recruitment, retention and engagement within hospitality organizations. International Journal of Contemporary Hospitality Management, 20(7), 743-757.

9. D'Annunzio-Green, N., Maxwell, G. A., \& Watson, S. (2000). Human resource issues in international hospitality, travel and tourism: a snapshot. International Journal of Contemporary Hospitality Management, 12(3), 215-216.

10. Fernández, L., Ventura, A. C., Andrade, J. C., Lumbreras, J., \& Cobo-Benita, J. R. (2017). The effect of clean development mechanism projects on human resource management practices in Brazil. International Journal of Operations \& Production Management, 37(10), 1348-1365.

11. Garavan, T. N., Morley, M., Gunnigle, P., \& Collins, E. (2001). Human capital accumulation: the role of human resource development. Journal of European industrial training, 25(2/3/4), 48-68.

12. Gholami, H., Rezaei, G., Saman, M. Z. M., Sharif, S., \&Zakuan, N. (2016). State-of-the-art Green HRM System: sustainability in the sports center in Malaysia using a multi-methods approach and opportunities for future research. Journal of Cleaner Production, 124, 142163.

13. Gu, Y., Tang, T., Wang, H., \& Zhou, W. (2019). Sustainable career development of new urban immigrants: A psychological capital perspective. Journal of Cleaner Production, 208, 1120-1130.

14. Hallier, J. (2001). Greenfield recruitment and selection: Implications for the older worker. Personnel Review, 30(3), 331-351.

15. Kim, Y. J., Kim, W. G., Choi, H. M., \&Phetvaroon, K. (2019). The effect of green human resource management on hotel employees' eco-friendly behavior and environmental performance. International Journal of Hospitality Management, 76, 83-93.

16. Kouhy, R., Vedd, R., Yoshikawa, T., \& Innes, J. (2009). Human resource policies, management accounting and organisational performance. Journal of Human Resource Costing \& Accounting, 13(3), 245-263.

17. Lebedev, Y., Anufriev, V., Lebedeva, T., Kaminov, A., \&Yachmenyova, A. (2015). Professional Training of Future Green Economy Specialists and Strategic Priorities for Sustainable Subsurface Management Procedia-Social and Behavioral Sciences, 214, 657-666.

18. Mishra, P. (2017). Green human resource management: A framework for sustainable organizational development in an emerging economy. International Journal of Organizational Analysis, 25(5), 762-788.

19. Moraes, S. D. S., ChiappettaJabbour, C. J., Battistelle, R A., Rodrigues, J. M., Renwick, D. S., Foropon, C., \&Roubaud, D. (2018). When knowledge management matters: interplay between green human resources and eco-efficiency in the financial service industry. Journal 
of Knowledge Management.

20. Ragas, S. F. P., Tantay, F. M. A., Chua, L. J. C., \&Sunio, C. M. C. (2017). Green lifestyle moderates GHRM's impact on job performance. International Journal of Productivity and Performance Management, 66(7), 857872.

21. Richbell, S., \& Doug Watts, H. (2001). Shades of green: the greenfield concept in HRM. Employee Relations, 23(5), 498-511.

22. Saini, P., \& Shukla. K. K. (2016). Green Recruitment: A New Tool of Cost Cutting. International Journal of Scientific and Innovative Research, 4(1), 195-198.

23. Siyambalapitiya, J., Zhang, X., \& Liu, X. (2018). Green Human Resource Management: A Proposed Model in the Context of Sri Lanka's Tourism Industry. Journal of Cleaner Production.

24. Tiwari, M. (2017). Green Orientation \& Green Management Practices as CSR in Academic Institutions. International Journal of Advance Research and Innovative Ideas in Education, 3(4), 668-676.

25. Valickas, A., Valickiene, R. P., \&Grakauskas, Z. (2015). Career Development And Learning In The Civil Service. Procedia-Social and Behavioral Sciences, 191, 413-417.

26. Yong, J. Y., \&Mohd-Yusoff, Y. (2016). Studying the influence of strategic human resource competencies on the adoption of green human resource management practices. Industrial and Commercial Training, 48(8), 416-422.

27. Yusliza, M. Y., Othman, N. Z., \&Jabbour, C. J. C. (2017). Deciphering the implementation of green human resource management in an emerging economy. Journal of Management Development, 36(10), 1230-1246. 